\title{
A Modified Phosphate-Carrier Protein Theory is Proposed as a Non-TARget Site Mechanism For Glyphosate Resistance in WEEDS ${ }^{1}$
}

\author{
Teoria das Proteinas Carregadoras Fosfato Modificadas Proposta como Mecanismo de \\ Resistência ao Herbicida Glyphosate em Plantas Daninhas
}

ROSO, A.C. ${ }^{2}$ and VIDAL, R.A. ${ }^{3}$

\begin{abstract}
Glyphosate is an herbicide that inhibits the enzyme 5-enolpyruvyl-shikimate-3phosphate synthase (EPSPs) (EC 2.5.1.19). EPSPs is the sixth enzyme of the shikimate pathway, by which plants synthesize the aromatic amino acids phenylalanine, tyrosine, and tryptophan and many compounds used in secondary metabolism pathways. About fifteen years ago it was hypothesized that it was unlikely weeds would evolve resistance to this herbicide because of the limited degree of glyphosate metabolism observed in plants, the low resistance level attained to EPSPs gene overexpression, and because of the lower fitness in plants with an altered EPSPs enzyme. However, today 20 weed species have been described with glyphosate resistant biotypes that are found in all five continents of the world and exploit several different resistant mechanisms. The survival and adaptation of these glyphosate resistant weeds are related toresistance mechanisms that occur in plants selected through the intense selection pressure from repeated and exclusive use of glyphosate as the only control measure. In this paper the physiological, biochemical, and genetic basis of glyphosate resistance mechanisms in weed species are reviewed and a novel and innovative theory that integrates all the mechanisms of non-target site glyphosate resistance in plants is presented.
\end{abstract}

Keywords: membrane carrier proteins, herbicide, weed resistance.

\begin{abstract}
RESUMO - Glyphosate é uma glicina fosfonada e inibe a enzima 5-enolpiruvil-shikimato-3-fosfato sintase (EPSPS) (EC 2.5.1.19). EPSPS é a sexta enzima da rota do shikimato, na qual são sintetizados os compostos do metabolismo secundário e os aminoácidos aromáticos fenilalanina, tirosina e triptofano. Alguns autores hipotetizaram que seria improvável a evolução de plantas daninhas resistentes a este herbicida. As justificativas estariam relacionadas à limitada metabolização de glyphosate nas plantas, ao baixo nível de resistência obtido com a superexpressão do gene EPSPS e à alta penalidade de adaptação oriunda de mutações no gene EPSPS. Mas, atualmente estão descritas 18 espécies com biótipos resistentes distribuidas em 17 paises. A sobrevivência e adaptação estão relacionadas aos mecanismos de resistência que ocorrem nas plantas daninhas selecionadas em função da intensa pressão de seleção do herbicida. Esta revisão objetiva apresentar e discutir evidências fisiológicas, bioquimicas e genéticas que fundamentam os principais mecanismos envolvidos na resistência ao herbicidaglyphosate em plantas daninhas.
\end{abstract}

Palavras-chave: herbicida, proteínas carregadoras de membrana, planta daninha.

1 Recebido para publicação em 220.8.2010 e na forma revisada em 17.12.2010.

2 Agronomist, M.Sc., Ph.D. student from the Programa de Pós-Graduação em Fitotecnia, Universidade Federal do Rio Grande do Sul - UFRGS; ${ }^{3}$ Agronomist, M.Sc., Ph.D., CNPq Fellow, Professor of the Programa de Pós-Graduação em Fitotecnia, UFRGS, $<$ ribas.vidal@gmail.com>. 


\section{INTRODUCTION}

The release of glyphosate resistant crops (soybean, corn, canola and cotton) beginning in the year 1996, resulted in a dramatic increase in the use of glyphosate herbicide (Owen, 2008). The broad scale use of this herbicide as the sole control measure and the lack of use of other complementary integrated weed control methods (eg., tillage) have led to the emergence of resistant weeds. This is a normal consequence of the high selection pressure generated by the continued use of a herbicide from only one mechanism of action.

The identification of all possible resistance mechanisms will allow the development of weed resistance management strategies based on physiological, biochemical, and genetic parameters. The objective of this review is to present all the physiological, biochemical, and genetic evidence related to glyphosate resistance mechanisms in weed species, and to propose a novel and innovative hypothesis to explain all the non target site glyphosate resistance mechanisms.

\section{GLYPHOSATE MODE OF ACTION}

The enzyme5-enolpyruvyl-shikimate-3phosphate synthase (EPSPs) (EC 2.5.1.19) is the sixth enzyme in the shikimate pathway, by which plants synthesize the aromatic amino acids phenylalanine, tyrosine, and tryptophan and other aromatic compounds used in secondary metabolism pathways in algae, plants, bacteria, and fungi (Kishore \& Shah, 1988; Bentley, 1990). To put this into perspective, the shikimate pathway consumes about $20 \%$ of the total carbon fixed in photosynthesis by a plant (Herrmann \& Weaver, 1999).

There are seven metabolic steps involved in the synthesis of aromatic amino acids phenylalanine, tyrosine, and tryptophan. It starts with the condensation of one molecule of phosphoenolpyruvate (PEP) and erytrose 4-phosphate (E4P) catalyzed by 3-deoxy-D arabino heptulosonato 7-phosphate synthase (DAHPS). In microorganisms, arogenate, an intermediate compound formed after chorismate, can function as a physiologic regulator of DAHPS. However, arogenate does not accumulate in plants at detectable levels suggesting that regulation of DAHPS in plants occurs preferentially at genetic levels (Rubin \& Jensen, 1985).

The crystal structure of the EPSPs enzyme revealed that in the presence of glyphosate, the two domains of the enzyme assume a closed conformation (Schonbrunn et al., 2001). This conformational shift leads to physical and chemical changes on the enzyme and thus compromises its catalytic function.

The genes encoding EPSPs show maximum expression first in meristems, then lastly in flowers and shoots. These genes are less expressed in mature leaves and cotyledons (Weaver \& Hermann, 1997). Studies have shown that tissue sensitivity to glyphosate was positively correlated with the level of the EPSPs gene expression (Feng et al., 2003). In fact, glyphosate at $0.2 \mathrm{mg} \mathrm{kg}^{-1}$ (w:w tissue) was enough to kill the shoot and root meristematic regions; whereas the compound only killed the stems at $8.4 \mathrm{mg} \mathrm{kg}^{-1}$ (Feng et al., 2003).

The gene that produces the EPSPs enzyme is encoded and transcribed in the nucleus (Stauffer et al., 2001). The mRNA is transported to the cytoplasm, where the EPSPs protein is synthesized. The EPSPs protein is then translocated to the chloroplast, where the synthesis of aromatic amino acids likely occurs.

The exact glyphosate action site location at subcellular level is unclear (Herrmann \& Weaver, 1997), because the cytoplasm contains the DAHPs enzyme and other enzymes involved in the biosynthesis of phenylpropanoids and flavonoids, whereas plastids do not contain them (Doong et al., 1992). Nevertheless, the occurrence of the shikimate pathway has been confirmed experimentally only in plastids (Schmid et al., 1992).

Despite this contradicting information, currently there is a strong evidence that glyphosate action site is at EPSPs enzyme (Schonbrunn et al., 2001; Wakelin \& Preston, 2006), corroborated by a subsequent decrease on the availability of aromatic amino acids tryptophan, phenylalanine and tyrosine. But, studies supplementing these amino acids in plants treated with glyphosate showed that herbicidal effects can not always be reversed, 
which suggests the possible existence of a secondary target site (Duke et al., 1980).

The action of glyphosate apparently can not be solely explained by the interference with protein synthesis. The interference in the allocation of carbon and the reduction in production of phenolic compounds also appear to be the main causes for reduced growth and death of plants in general (Duke et al., 1980).

Despite the use of this herbicide over many years and the massive amount of research on this topic, there are still many questions regarding its mode of action. Answering these questions would be extremely important to understand the evolution of resistant weeds and to elucidate the mechanisms involved in weeds resistance to this herbicide.

\section{WEED RESISTANCE TO HERBICIDES}

The resistance of weeds to herbicides limits the number of alternatives that can be employed to control weeds. Resistance arises as a function of the selection pressure generated by the continuous use of the same herbicide or mode of action through either independent evolution or gene flow. The dynamics of weed resistance to herbicides depends on factors related to: the genetics of resistant genes (frequencies in population, copy number, dominance and fitness cost of resistant genes), weed biology (outcrossing or self-pollinated, seed production capacity, dormancy, seed and pollen dispersal mechanisms), the herbicide (site of action, chemical structure, level of activity to the particular weed, residual activity) and management practices (herbicide rate, application frequency, crop management) (Powles \& Yu, 2010).

Worldwide, there are currently 346 resistant biotypes, totaling 194 species resistant to herbicides with different modes of action, and distributed over 60 countries (Heap, 2010). In Brazil, there are 29 resistant weed species confirmed. From these, three exhibit resistance to multiple herbicides: Bidens subalternans (to acetolactate synthase (ALS) inhibitors and to photosystem II inhibitors) (Heap, 2010); Echinochloa crusgalli (to ALS inhibitors and synthetic auxins) (Heap, 2010), Euphorbia heterophylla (to ALS inhibitors and to PROTOX inhibitors) (Trezzi et al., 2005), and Euphorbia heterophylla (to ALS inhibitors and to EPSPS inhibitors) (Vidal et al., 2007).

\section{EVOLUTION OF GLYPHOSATE RESISTANT WEEDS}

Although glyphosate has been commercialized since 1974 (Vidal \& Merotto Jr., 2001), the first reports of weeds resistant to glyphosate came in 1996, which lead many authors to believe that weed resistance to glyphosate would be unlikely to occur (Waters, 1991; Jasieniuk, 1995; Bradshaw et al., 1997). Three main reasons were presented to support this hypothesis. First, glyphosate is slowly metabolized by plants. Second, overexpression of EPSPs gene confers low levels of resistance. Third, mutations on EPSPs gene were associated with high fitness penalties (Waters, 1991; Jasieniuk, 1995; Bradshaw et al., 1997).

Over a decade later following an increase in the problem and after many additional studies have been conducted, this hypothesis can be challenged. Currently there have been reports of at least 102 different biotypes with resistance to glyphosate. These biotypes belong to 20 weed species and can be divided into eleven dicotyledonous and nine monocotyledonous species (Table 1).

The first case of glyphosate-resistant weed was reported for Lolium rigidum, found in Australia (Powles et al. 1998; Pratley et al. 1999). In Brazil, the first glyphosate-resistant weed reported was Lolium multiflorum (Roman et al., 2004; Vargas et al., 2004). Glyphosateresistant weeds are currently distributed throughout 17 countries, with the majority of them located in North America (13 species); followed by $\mathrm{S}$ America (10 species); and the other continents with 14 species (Table 1).

Some authors (Cerdeira \& Duke, 2006; Vila-Aiub et al., 2008) speculate that the release of glyphosate resistant crops (soybeans, corn, cotton and canola) during the mid-1990's have exacerbated the increase of glyphosate resistant weeds. The intensive use of herbicide from only one mode of action and lack of other integrated weed management practices, i.e., increase in no-tillage, have generated a high selection pressure which could have driven the rapid evolution of 
Table 1 - Glyphosate resistant weeds by species, number of biotypes* and total of species by location** (Adapted from Heap, 2010)

\begin{tabular}{|c|c|c|c|c|c|c|c|}
\hline \multirow{2}{*}{ Specie } & \multirow{2}{*}{ Biotype } & \multicolumn{6}{|c|}{ Location of glyphosate resistant weeds } \\
\hline & & Africa & N America & S America & Asia & Oceania & Europe \\
\hline Amaranthus palmerii & $10^{*}$ & & $\mathrm{X}$ & & & & \\
\hline Amaranthus rudis & 6 & & $\mathrm{X}$ & & & & \\
\hline Ambrosia arthemisiifolia & 4 & & $\mathrm{X}$ & & & & \\
\hline Ambrosia trifida & 10 & & $\mathrm{X}$ & & & & \\
\hline Conyza bonariensis & 8 & $\mathrm{X}$ & $\mathrm{X}$ & $\mathrm{X}$ & $\mathrm{X}$ & & $\mathrm{X}$ \\
\hline Conyza canadensis & 22 & & $\mathrm{X}$ & $\mathrm{X}$ & $\mathrm{X}$ & & $\mathrm{X}$ \\
\hline Conyza sumatrensis & 1 & & & & & & $\mathrm{X}$ \\
\hline Digitaria insularis & 3 & & & $\mathrm{X}$ & & & \\
\hline Echinochloa colona & 1 & & & & & $\mathrm{X}$ & \\
\hline Eleusine indica & 3 & & & $\mathrm{X}$ & $\mathrm{X}$ & & \\
\hline Euphorbia heterophylla & 1 & & & $\mathrm{X}$ & & & \\
\hline Kochia scoparia & 2 & & $\mathrm{X}$ & & & & \\
\hline Lolium multiflorum & 11 & & $\mathrm{X}$ & $\mathrm{X}$ & & & $\mathrm{X}$ \\
\hline Lolium perene & 1 & & & $\mathrm{X}$ & & & \\
\hline Lolium rigidum & 12 & $\mathrm{X}$ & $\mathrm{X}$ & & & $\mathrm{X}$ & $\mathrm{X}$ \\
\hline Parthenium hysterophorus & 1 & & & $\mathrm{X}$ & & & \\
\hline Plantago lanceolata & 1 & $\mathrm{X}$ & & & & & \\
\hline Poa аппиа & 1 & & $\mathrm{X}$ & & & & \\
\hline Sorghum halepense & 3 & & $\mathrm{X}$ & $\mathrm{X}$ & & & \\
\hline Urochloa panicoides & 1 & & $\mathrm{X}$ & & & $\mathrm{X}$ & \\
\hline Total & $102 *$ & $3 * *$ & 13 & 10 & 3 & 3 & 5 \\
\hline
\end{tabular}

resistant weeds (Cerdeira \& Duke, 2006; Vila-Aiub et al., 2008). The survival of the glyphosate resistant biotypes is due to biochemical, genetic and molecular mechanisms selected by the herbicide.

\section{Glyphosate resistance mechanisms}

Glyphosate resistance mechanisms are known for only 11 out of a total of 18 species described as having resistance. The mechanisms of glyphosate resistance can be divided into two groups: those involving changes on target site and those not related to herbicide target site (Powles \& Preston, 2006; Powles \& Yu, 2010). Mutations at target site and gene amplification are examples of target site resistance mechanisms. Reduced absorption, metabolism, low translocation and sequestration in the vacuole are examples of non-target site resistance mechanisms (Powles \& Shaner, 2001; Powles \& Yu, 2010). The most commonly reported mechanisms for glyphosate resistance are reduced absorption and translocation (Table 2).

\section{Glyphosate resistance mechanisms involving herbicide target site}

\section{Target-site mutations}

Weeds susceptible to herbicides, in general, have an enzyme which is inhibited by the herbicide molecule. This enzyme has an important role in the survival of plants, which is why when it is inhibited it leads to the death of the weed. The specific plant enzyme that is inhibited by each herbicide is known as the site of action. Thus, herbicides are classified according to enzymes they inhibit (Vidal \& Merotto Jr., 2001).

Target site resistance mechanism is endowed by mutations at the gene that encodes the enzyme. These mutations are typically nucleotide substitutions (Tranel \& Wright, 2002), but there are one report of deletion of one entire codon of amino acids (Patzoldt et al., 2006).

The first reported case of target site resistance for glyphosate was reported in 
biotypes of Eleusine indica (ELEIN) from Malaysia, in which mutations in EPSPs gene caused the substitution of amino acid proline to serine at position $106\left(\mathrm{P}_{106} \mathrm{~S}\right)$ (Baerson et al., 2002). The resistance factor in these population was found to be five, in other words, the resistant biotypes were five-fold less sensitive than the susceptible biotypes. Other resistant biotypes of ELEIN from Malaysia were found to have the mutation $\mathrm{P}_{106} \mathrm{~T}$ ( $\mathrm{Ng}$ et al., 2003). The $P_{106}$ T mutation was also detected in a population of Lolium rigidum from Australia (Wakelin \& Preston, 2006) and in a population of Lolium multiflorum from Chile (Perez-Jones et al., 2007).

ELEIN biotypes from the Philippines also were found to have the $\mathrm{P}_{106} \mathrm{~S}$ mutation which gave a resistance factor of 2.8 (Kaundun et al., 2008). The resistance factor associated with the $\mathrm{P}_{106} \mathrm{~T}$ mutation was found to be 3.4 in resistant biotypes of Lolium rigidum from Australia (Wakelin \& Preston, 2006). However, another amino acid mutation found in the same position $\mathrm{P}_{106} \mathrm{~A}$ in Lolium multiflorum from California, gave a resistance factor of 15 (Jasieniuk et al., 2008). These results suggest that different amino acid substitutions on
EPSPs gene at position 106 replacing the amino acid proline may led to conformational differences in the enzyme, which causes different resistance levels according to the substitution. However, resistance levels associated with this resistance mechanism, in general, are smaller than those found in weeds resistant to glyphosate due to non-target site resistant mechanisms.

Additionally, a Lolium rigidum biotype, from South Africa has been found with multiple resistance to glyphosate, paraquat and ACCase inhibitors. This multiple resistant weed had two glyphosate resistance mechanisms, the $\mathrm{P}_{106} \mathrm{~A}$ mutation and reduced translocation. The level of resistance in this biotype was found to be additive when compared to biotypes where resistance was due to only one mechanism of resistance (Yu et al., 2007).

\section{Gene amplification}

Another mechanism for glyphosate resistance was identified recently in biotypes of Amaranthus palmeri from Georgia, USA (Gaines et al., 2010). The number of EPSPs gene copies in susceptible population ranged

Table 2 - Glyphosate resistance mechanisms identified in 11 weed species

\begin{tabular}{|c|c|c|}
\hline Resistant mechanism & Weed & Reference \\
\hline \multicolumn{3}{|c|}{ Target site } \\
\hline Mutations & $\begin{array}{l}\text { Eleusine indica , Lolium rigidum , Lolium } \\
\text { multiflorum }\end{array}$ & $\begin{array}{l}\text { Baerson et al. (2002); Ng et al. (2003); Wakelin \& } \\
\text { Preston (2006); Perez-Jones et al. (2007); Yu et al. } \\
\text { (2007); Kaundun et al. (2008); Jasieniuk et al. } \\
\text { (2008) }\end{array}$ \\
\hline Gene amplification & Amaranthus palmeri & Gaines et al. (2010) \\
\hline \multicolumn{3}{|c|}{ Non-target site } \\
\hline Metabolization & - & - \\
\hline Low absortion & Lolium multifl orum, Lolium rigidum & Michite et al. (2007); Nandula et al. (2008) \\
\hline Vacuole Sequestration & Conyza canadensis & Ge et al. (2010) \\
\hline Reduced translocation & $\begin{array}{l}\text { Lolium multiflorum, Lolium rigidum } \\
\text { Conyza canadensis, Conyza bonariensis }\end{array}$ & $\begin{array}{l}\text { Lorraine -Colwill et al. (2003); Feng et al. (2004); } \\
\text { Wakelin et al. (2004); Koger \& Reddy (2005); } \\
\text { Michite et al. (2007); Dinelli et al. (2008); Ferreira } \\
\text { et al. (2008); Nandula et al. (2008); Preston et al. } \\
\text { (2009); Yu et al. (2009) }\end{array}$ \\
\hline
\end{tabular}


from 1 to 1.3 , whereas in resistant biotype this number ranged from 5 to more than 160 copies of the gene. The number of gene copies was strongly correlated with EPSPs enzyme expression. This enzyme in the resistant biotype expressed 35-fold more compared to the susceptible biotype. Also, the higher number of EPSPs gene copies resulted in an increased level of expressed mRNA, which consequently, leads to higher levels of glyphosate resistance (Gaines et al., 2010).

This was the first report in the literature of a resistance mechanism involving gene amplification. Analysis of fluorescence in situ hybridization has shown that EPSPs gene copies were present on almost all chromosomes of the genome of $A$. palmeri and appeared to be distributed randomly (Gaines et al., 2010). The high number of copies and their location on the genome suggests the action of transposon-like proteins or RNAmediated mechanisms. Many transposons are inactive in plants, but can become active in response to certain abiotic stresses (Lisch, 2009). Further research is needed to elucidate which factors or proteins would activate the action of these transposons. The key to understanding EPSPs gene amplification mechanism remains to be elucidated.

\section{Non-target site glyphosate resistance mechanisms}

\section{Enhanced metabolism}

Plants resistant to herbicides by enhanced metabolism have the ability to decompose chemical molecule faster than sensitive plants, rendering them inactive before they can reach the site of action and bind to the target site. The most common routes involved in herbicide metabolism are hydrolysis, oxidation, and reduction pathways. In some species, certain parts of the herbicide molecule can be conjugated to glutathione (GSH) and amino acids following the first steps in the metabolic pathways (Kreuz et al., 1996). Cytochrome $\mathrm{P}_{450}$-monooxygenase plays a key role in metabolization through oxidation pathways and results in the hydroxylation of aromatic rings (Kreuz et al., 1996).

To date, there have been no reports in the literature of weeds resistant to glyphosate due to enhanced metabolism. However, weed tolerance to this compound has been identified in monocot weed Commelina benghalensis, where $41 \%$ of the applied glyphosate has been converted to metabolite AMPA at 72 hours after the treatment (Monquero et al., 2004). It is possible that some resistant weed species may have the ability to metabolize glyphosate as a resistance mechanism.

\section{Reduction of absorption or translocation}

Among all currently identified glyphosate resistance mechanisms, either the reduction of absorption or translocation are the most important. In the first reported case of glyphosate resistance, Lolium rigidum from Australia (Powles et al. 1998; Pratley et al. 1999), studies showed that resistance was not due to an insensitive EPSPs enzyme or enhanced metabolism (Lorraine-Colwill et al., 2003). These authors instead observed accumulation of glyphosate in the leaf tip of the resistant biotype and accumulation of the herbicide in meristems of the susceptible biotype. The same pattern of resistance was identified in four other different populations of L. rigidum from Australia (Wakelin et al., 2004).

A L. rigidum biotype with the $\mathrm{P}_{106} \mathrm{~T}$ mutation (Wakelin \& Preston, 2006) was crossed with the resistant biotype with reduced translocation (Lorraine-Colwill et al., 2003). The F1 population showed a superior resistance factor when compared to that of both parents, demonstrating that different glyphosate resistance mechanisms can be additive (Preston et al., 2009). The intersection of population with different resistance mechanisms leading to their addition may increase the overall weed resistance problem and may make it more difficult to manage weeds in particular crops (Yu et al., 2007; Preston et al., 2009).

Reduced glyphosate absorption and translocation has also been found in Lolium multiflorum from Chile. In fact, resistant biotypes of this species show reduced glyphosate absorption through the abaxial leaf surface and higher concentration of ${ }^{14} \mathrm{C} 1180$-glyphosate at the tip of the leaves (Michitte et al., 2007). Reduction of absorption 
and translocation of glyphosate were also identified in L. multiflorum from Mississippi (Nandula et al., 2008).

Accumulation of glyphosate in the treated leaf was identified in resistant biotypes of Conyza canadensis from U.S., and Conyza bonariensis from Spain and Brazil (Feng et al., 2004, Koger \& Reddy, 2005; Dinelli et al., 2008, Ferreira et al. 2008). The results suggest that glyphosate is either trapped within the treated leaf or it is not being translocated out and can not reach its site of action.

After absorption occurs, a herbicide would normally move with the transpiration flow and would be loaded into the phloem in order to reach the site of action located inside the plastids of the meristems. However, it has been speculated that an unidentified barrier that prevents glyphosate entry into the phloem and/or the presence of some carrier protein that impedes the presence of the herbicide on the sensitive tissue results in lack of phloem loading of the herbicide in resistant weeds. Four different hypotheses have been proposed (Shaner, 2009) to explain the mechanism of reduced translocation: a) change in the transporter that carries the glyphosate into the cell; b) increased action of a transporter that carries the glyphosate into the vacuole; c) increased active efflux pumps of glyphosate; d) increased action of a transporter that carries glyphosate out of the chloroplast. We propose two additional hypotheses to explain the lack of glyphosate inside the chloroplast: e) reduced movement of the herbicide through the transpiration flow, and f) inability of the herbicide to reenter the phloem.

In fact, we propose all these hypotheses can be integrated into a Modified PhosphateCarrier Protein Theory. Because the strong binding properties of the phosphonate moiety of glyphosate (Godoy, 2007), it is possible any membrane phosphate protein-carrier may have a role on shuttling this herbicide across membranes. Thus, one or more of several types of carrier proteins may be involved in the resistance evolution (Figure 1). Candidate carrier protein include: carriers of phosphorus, $\mathrm{ABC}$ transporters, and transporters of the chloroplast or vacuole. A gene mutation (point mutation, deletion, insertion, amplification, among other mechanisms) on the genes that encode for these proteins would explain the reduced translocation, increased vacuolization, reduced phloem upload, cell exclusion, among other processes.

The literature provides evidence of possible candidate genes to substantiate the Modified Phosphate-Carrier Protein Theory. Phosphate transporter proteins present in the membranes of Vicia faba and Catharanthus roseus have been shown to facilitate the absorption of glyphosate (Denis \& Delrot, 1993, Morin et al., 1997).

Other carrier genes involved with phosphate transport may be candidates for investigation about their potential involvement in glyphosate resistance phenomenon. For instance, the Ph $1 ; 6$ gene, which encodes a transporter of low affinity of phosphorus and is highly expressed in shoots (Rae et al., 2003), may be a possible candidate gene involved in the cell exclusion of glyphosate. Likewise, the $\mathrm{Ph} 2 ; 1$ gene, that is encoded in the plastids (Rausch et al., 2004) may be involved in the chloroplast exclusion of glyphosate.

ABC transporters comprise a large family with more than 130 genes that have many roles in the cell, including: excretion of toxic compounds, sequestration of secondary metabolites, and translocation of lipids and phospholipids (Yuan et al., 2007). The transformed plant Arabidopsis thaliana overexpressing an $\mathrm{ABC}$ transporter gene has been shown to exhibit resistance to the herbicides pendimenthalin, dicamba and MSMA (Windsor et al., 2003).

A study using ${ }^{31} \mathrm{P}$ magnetic resonance on Conyza canadensis resistant to glyphosate investigated the distribution of glyphosate in the vacuole and in the cytoplasm. Major herbicide peaks were observed in the vacuoles of the resistant biotypes 44 hours after treatment with $3.3 \mathrm{~kg} \mathrm{ha}^{-1}$ glyphosate (Ge et al., 2010). The flow of glyphosate into the vacuole is considered to be a new non-target mechanism of glyphosate resistance, but the exact proteins involved in this process remain to be elucidated. Studies that use proteomics have highlighted a tonoplast protein expressed only in the resistant $C$. canadensis biotype but not in susceptible biotypes (Yuan et al., 2010). 


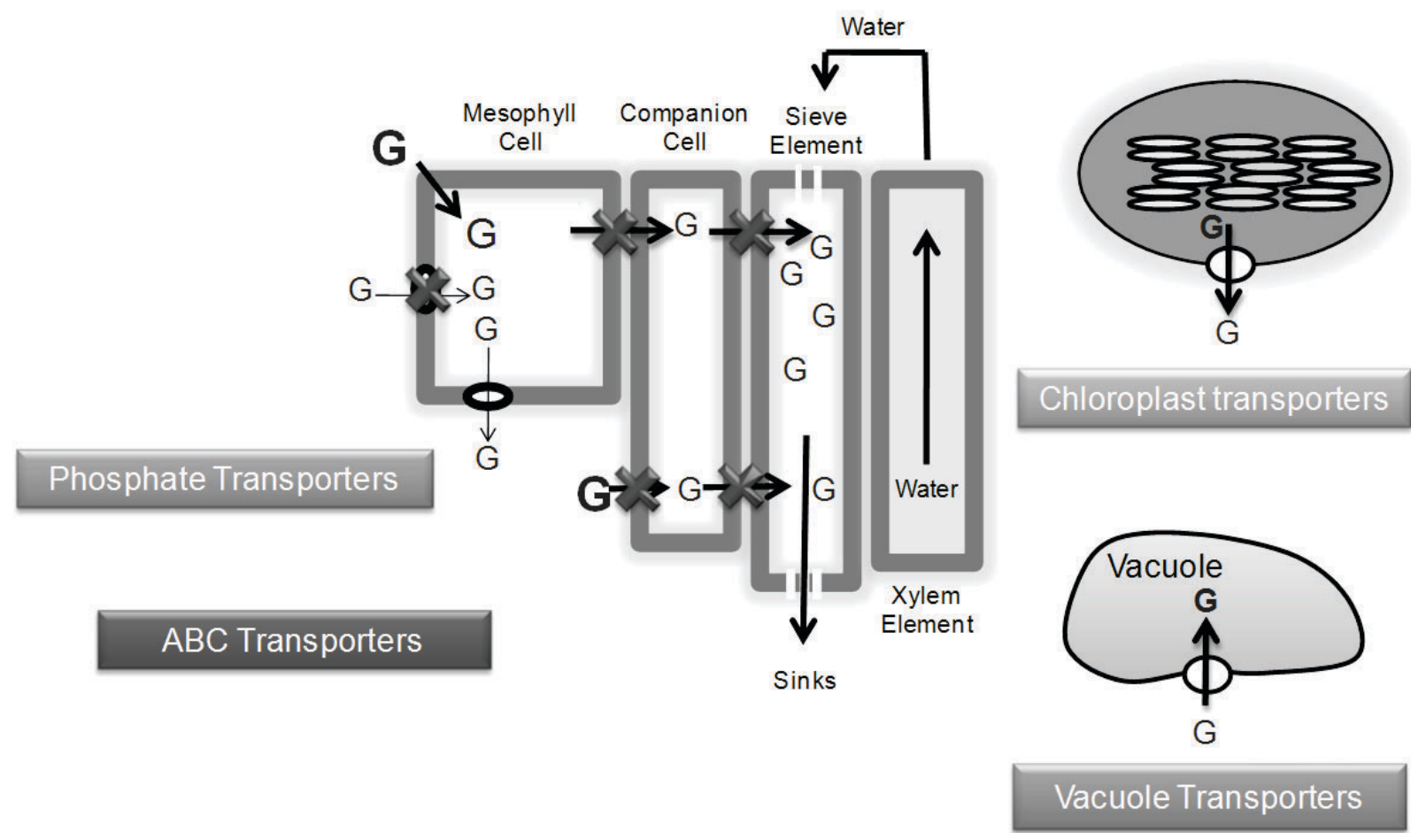

Figure 1 - Proposed Modified Phosphate-Carrier Theory explaining the glyphosate resistance mechanism due to reduced translocation, possibly mediated by different phosphate-carrier proteins. (Expanded in this paper after Shaner, 2009).

The use of functional genomics may help to identify the transporter proteins involved in the vacuolization of glyphosate, thus clarifying the exact molecular mechanism involved in this type of resistance.

\section{FINAL OVERVIEW}

The mechanisms of glyphosate resistance in weeds are divided into two major groups: those involving target site, and those not related to herbicide target site. Currently, the most frequent type of glyphosate resistance mechanism is the compound reduced translocation. Recently, the sequestration of the herbicide in the vacuole has been identified as an important mechanism of glyphosate resistance in weeds.

Little is known about the causes of reduced translocation or increased vacuolization of glyphosate. This review hypothesizes that phosphate-transporter proteins present in cell membranes acting together or in isolation may be involved in this type of glyphosate resistance. If this assumption is correct, any modification on the genes that produces these proteins are prone to mutate, thus altering the plant phenotype (to glyphosate resistance, for instance). The candidate genes for the proposed theory are: carriers of phosphorus, $\mathrm{ABC}$ transporters, and transporters of the chloroplast or vacuole. This Phosphate CarrierMediated Theory is based on indirect evidence and possible candidate genes that could play a role in this mechanism of resistance were suggested.

Other glyphosate resistance mechanisms have recently been discovered, such as EPSPs enzyme amplification. Many processes of plant cell gene and function can be revealed with progress in the scientific research elucidating the mechanisms of glyphosate resistant in weeds. However, as important as discovering the mechanisms of glyphosate resistance, it is necessary to integrate these findings into weed management strategies, to limit the expansion of the area with herbicide resistant weeds. 


\section{ACKNOWLEDGMENTS}

This work was supported by CAPES and CNPQ (Brazilian Research Agencies). The suggestions of Drs. Harry J. Strek (Bayer Crop Sciences, Germany) and Nelson D. Kruse (Universidade Federal de Santa Maria, Brazil) to an early draft of this paper are appreciated.

\section{LITERATURE CITED}

BAERSON, S. R. et al. Glyphosate-Resistant goosegrass. identification of a mutation in the target enzyme 5enolpyruvylshikimate-3-phosphate synthase. Plant Physiol., v. 129, n.3, p. 1265-1275, 2002

BENTLEY, R. The shikimate pathway - a metabolic tree with many branches. Crit. Rev. Biochem. Molec. Biol., v. 25, n. 1, p. 307-384, 1990.

BRADSHAW, L. D. et al. Perspectives on glyphosate resistance. Weed Technol., v. 11, n. 1, p. 189-198, 1997.

CERDEIRA, A. L.; DUKE, S. O. The current status and environmental impacts of glyphosate-resistant crops; a review. J. Environ. Quality, v. 35, n. 5, p. 1633-1658, 2006.

DENIS, M. H.; DELROT, S. Carrier-mediated uptake of glyphosate in broad bean (Vicia faba) via a phosphate transporter. Physiol. Plant., v. 87, n. 4, p. 569-575, 1993

DINELLI, G. et al. Physiological and molecular bases of glyphosate resistance in Conyza bonariensis biotypes from Spain. Weed Res., v. 48, n. 3, p. 257-265, 2008

DOONG, R. L. et al. The cytosolic isoenzyme of 3-deoxy-Darabino-heptulosonate 7-phosphate synthase in Spinacia oleracea and other higher plants: extreme substrate ambiguity and other properties. Physiol. Plant., v. 84, n. 3, p. 351-360, 1992.

DUKE, S. O. et al. Effects of glyphosate on metabolism of phenolic compounds. Plant Physiol., v. 65, n. 1, p. 17-21, 1980 .

FENG, P. C. C. et al. Investigations into glyphosate-resistant horseweed (Conyza canadensis): retention, uptake, translocation, and metabolism. Weed Sci., v. 52, n. 4, p. 498505, 2004.

FENG, P. C. C. et al. Glyphosate efficacy is contributed by its tissue concentration and sensitivity in velvetleaf (Abutilon theophrasti). Pestic. Biochem. Physiol., v. 77, n. 1, p. 83-91, 2003.

FERREIRA, E. A. et al. Glyphosate translocation in hairy fleabane (Conyza bonariensis) biotypes. Planta Daninha, v. 26, n. 3 , p. $637-643,2008$
GAINES, T. A. et al. Gene amplification confers glyphosate resistance in Amaranthus palmeri. Proc. National Academy Sci. USA, v. 107, n. 3, p. 1029-1034, 2010.

GE, X. et al. Rapid vacuolar sequestration: the horseweed glyphosate resistance mechanism. Pest Manag. Sci., v. 66, n. 4 , p. $345-348,2010$.

GODOY, M. C. Efeitos do glyphosate sobre o crescimento e absorção do fósforo pela soja. 2007. 43 f. Dissertação (Mestrado em Agricultura) - Universidade Estadual Paulista, Botucatu, 2007.

HEAP, I. International survey of herbicide resistant weeds. Disponível em: http://www.weedscience.org. Acessado em: abril de 2010.

HERRMANN, K. M.; WEAVER, L. M. The shikimate pathway. Ann. Rev. Plant Physiol. Plant Molec. Biol., v. 50, n. 1, p. 473-503, 1999.

JASIENIUK, M. Constraints on the evolution of glyphosate resistance in weeds. Resistant Pest Manag. Newsletter, v. 7, n. 2 , p. $31-32,1995$.

JASIENIUK, M. et al. Glyphosate-resistant Italian ryegrass (Lolium multiflorum) in California: distribution, response to glyphosate, and molecular evidence form an altered target enzyme. Weed Sci., v. 56, n. 5, p. 496-502, 2008.

KAUNDUN, S. S. et al. Importance of the P106S target-site mutation in conferring resistance to glyphosate in a goosegrass (Eleusine indica) population from Philippines. Weed Sci., v. 56, n. 5, p. 37-646, 2008.

KISHORE, G. M.; SHAH, D. M. Amino acid biosynthesis inhibitors as herbicides. Ann. Rev. Biochem., v. 7, p. 27-663, 1988.

KOGER, C. H.; REDDY, K. N. Role of absorption and translocation in the mechanism of glyphosate resistance in horseweed (Conyza canadensis). Weed ci., v. 3, n. 1, p. 84-89, 2005

KREUZ, K. et al. Old enzymes for a new job. Plant Physiol., v. 111, n. 2, p. 349-353, 1996.

LISCH, D. Epigenetic regulation of transposable elements in plants. Ann. Rev. Plant Biol., v. 60, n. 1, p. 46-66, 2009.

LORRAINE-COLWILL, D. F. et al. Investigations into the mechanisms of glyphosate resistance in Lolium rigidum Pestic. Biochem. Physiol., v. 74, n. 2, p. 62-72, 2003

MICHITTE, P. et al. Mechanisms of resistance to glyphosate in a ryegrass (Lolium multiflorum) biotype from Chile. Weed Sci., v. 55, n. 5, p. 435-440, 2007. 
MONQUERO, P. A. et al. Absorção, translocação e metabolismo do glyphosate por plantas tolerantes e suscetíveis a este herbicida. Planta Daninha, v. 22, n. 3, p. 445-451, 2004.

MORIN, F. et al. Glyphosate uptake in Catharanthus roseus cells: role of a phosphate transporter. Pestic. Biochem. Physiol., v. 58, n. 1, p. 13-22, 1997.

NANDULA, V. K. et al. Glyphosate tolerance mechanism in Italian Ryegrass (Lolium multiflorum) from Mississippi. Weed Sci., v. 56, p. 344-349, 2008.

NG, C. H. et al. Gene polymorphisms in glyphosate-resistant and -susceptible biotypes of Eleusine indica from Malaysia. Weed Res., v. 43, n. 2, p. 108-115, 2003.

OWEN, M. D. K. Weeds species shifts in glyphosate-resistant crops. Pest Manag. Sci., v. 64, n. 4, p. 377-387, 2008.

PATZOLDT, W. L. et al. A codon deletion confers resistance to herbicides inhibiting protoporphyrinogen oxidase. Proc.

National Academy Sci. USA, v. 103, p. 12329-12334, 2006.

PEREZ-JONES, A. et al. Investigating the mechanisms of glyphosate resistance in Lolium multiflorum.

Planta Daninha, v. 226, n. 2, p. 395-404, 2007.

POWLES, S. B.; PRESTON, C. Evolved glyphosate resistance in plants: biochemical and genetic basis of resistance. Weed Technol., v. 20, n. 2, p. 282-289, 2006

POWLES, S. B.; YU, Q. Evolution in action: plants resistant to herbicides. Ann. Rev. Plant Biol., v. 61, n. 1, p. 317-347, 2010 .

POWLES, S. B. \& SHANER, D. L. Herbicide resistance and world grains. Boca Raton: CRC Press, 2001. 308 p.

POWLES, S. B. et al. Evolved resistance to glyphosate in rigid ryegrass (Lolium rigidum) in Australia. Weed Sci., v. 46, p. 604-607, 1998.

PRATLEY, J. E. et al. Resistance to glyphosate in Lolium rigidum: I. Bioevaluation. Weed Sci., v. 47, p. 405-411, 1999

PRESTON, C. et al. A decade of glyphosate-resistant Lolium around the world: mechanisms, genes, fitness, and agronomic management. Weed Sci., v. 57, p. 435-441, 2009.

RAE, A. L. et al. Characterization of two phosphate transporters from barley; evidence for diverse function and kinetic properties among members of the Pht1 family. Plant Molec. Biol., v. 53, n. 1, p. 27-36, 2003.

RAUSCH, C. et al. Expression analysis suggests novel roles for plastidic phosphate transporter Pht 2;1 in auto and heterotrophic tissues in potato and Arabidopsis. Plant J., v. 39, n. 1, p. 13-28, 2004.
ROMAN, E. S. et al. Resistência de azevém (Lolium multiflorum) ao herbicida glyphosate. Planta Daninha, v. 22, n. 2, p. 301-306, 2004.

RUBIN, J. L.; JENSEN, R. A. Differentially regulated isozymes of 3-deoxy-D-arabino-heptulosonate 7-phosphate synthase in Vigna radiate (L.) Wilcczek. Plant Physiol., v. 79, n. 3 , p. 711-718, 1985.

$\mathrm{SCHMD}$, J. et al. The in vitro synthesized tomato shikimate kinase precursor is enzymatically active and is imported and processed to the mature enzyme by chloroplasts. Plant J., v. 2 , n. 3 , p. $375-383,1992$

SCHMID, J. et al. The in vitro synthesized tomato shikimate kinase precursor is enzymatically active and is imported and processed to the mature enzyme by chloroplasts. Plant J., v. 2, n. 3 , p. $375-383,1992$

SCHONBRUNN, E. et al. Interaction of the herbicide glyphosate with its target enzime 5-enolpyruvylshikimate 3-phosphate synthase in atomic detail. Proc. National Academy Sci. USA, v. 98, n. 4, p. 1376-1380, 2001

SHANER, D. L. Role of translocation as a mechanism of resistance to glyphosate. Weed Sci., v. 57, n. 1, p. 118-123, 2009.

STAUFFER, M. E. et al. Chemical shift mapping of shikimate 3-phosphate binding to the isolated N-terminal domain of 5-enolpyruvylshikimate-3-phosphate synthase Federation of European. Biochem. Soc., v. 499, n. 1, p. 182-186, 2001.

TRANEL, P. J.; WRIGHT, T. R. Resistance of weeds to ALS-inhibiting herbicides: what have we learned? Weed Sci., v. 50, n. 6, p. $700-712,2002$

TREZZI, M. M. et al. Multiple resistance of acetolactate synthase and protoporphyrinogen oxidase inhibitors in Euphorbia heterophylla biotypes. J. Environ. Sci. Health. Part B, Pestic. Food Contam. Agric. Wastes, v. 40, n. 1, p. 101-109, 2005.

VARGAS, L. et al. Identification of glyphosate-resistant ryegrass (Lolium multiflorum) biotypes in apple orchards. Planta Daninha, v. 22, n. 4, p. 617-622, 2004.

VIDAL, R. A.; MEROTTO JR., A. Herbicidologia. Porto Alegre: EVANGRAF, 2001. 152 p.

VIDAL, R. A. et al. Glyphosate resistant biotypes of wild poinsettia (Euphorbia heterophylla (L.)) and its risk analysis on glyphosate-tolerant soybeans. J. Food Agric. Environ., v. 5 , n. 2 , p. $265-269,2007$

VILA-AIUB, M. M. et al. Glyphosate-resistant weeds of South American cropping systems: an overview. Pest Manag. Sci., v. 64, n. 4, p. 366-371, 2008 
WAKELIN, A. M. et al. Glyphosate resistance in four different populations of Lolium rigidum is associated with reduced translocation of glyphosate to meristematic zones Weed Res., v. 44, n. 6, p. 453-459, 2004

WAKELIN, A. M.; PRESTON, C. A target site mutation is present in a glyphosate-resistant Lolium rigidum population. Weed Res., v. 46, n. 5, p. 432-440, 2006

WATERS, S. Glyphosate tolerant crops for the future: development, risks, and benefits. In: BRIGHTON CROP PROTECTION CONFERENCE: WEEDS, 1991, Farnham. Proceedings... Farnham: BCPC Registered Office, 1991. p. $165-170$

WEAVER, L. M.; HERRMANN, K. M. Dynamics of the shikimato pathway in plants. Trends Plant Sci., v. 2, n. 9, p. 346-351, 1997.
WINDSOR, B. et al. Multiherbicide tolerance conferred by AtPgp1 and apyrase overexpression in Arabidopsis thaliana. Nature Biotechnol., v. 21, n.4, p. 428-433, 2003.

YU, Q. et al. Distinct non-target site mechanisms endow resistance to glyphosate, ACCase and ALS-inhibiting herbicides in multiple herbicide-resistant Lolium rigidum. Planta, v. 230, n. 4, p. 713-723, 2009.

YU, Q. et al. Glyphosate, paraquat and ACCase multiple herbicide resistance evolved in a Lolium rigidum biotype. Planta, v. 225, n. 2, p. 499-513, 2007.

YUAN, J. S. et al. Non-target-site herbicide resistance: A family business. Trends Plant Sci., v. 12, n. 1, p. 6-13, 2007.

YUAN, J. S. et al. Functional genomics analysis of horseweed (Conyza canadensis) with special reference to the evolution of non-target-site glyphosate resistance. Weed Sci., v. 58, n. 1, p. 109-117, 2010. 